\title{
Arbitration on Margin Positions Liquidation at Stock Exchange in India*
}

\author{
B. Brahmaiah \\ Department of Finance \& Accounting, ICFAI Business School, IFHE, Hyderabad, India \\ Email: brahmaiahb@yahoo.com
}

How to cite this paper: Brahmaiah, B. (2018) Arbitration on Margin Positions Liquidation at Stock Exchange in India. Theoretical Economics Letters, 8, 1701-1708. https://doi.org/10.4236/tel.2018.810110

Received: April 19, 2018

Accepted: June 16, 2018

Published: June 19, 2018

Copyright (C) 2018 by author and Scientific Research Publishing Inc. This work is licensed under the Creative Commons Attribution International License (CC BY 4.0).

http://creativecommons.org/licenses/by/4.0/

\begin{abstract}
The paper investigates compliances of margin trading rules and regulations of the Stock Exchange by stock brokers in India. Trading practices, misuses and abuses of securities market by trading members have been discussed in detail in this paper. It highlights how some trading members violate the margin trading rules and misinterpret the regulatory compliances. The award provides inputs for the development of appropriate regulatory framework for the securities market. A discussion on capital market abuses would promote customer education and their curtailment by the competent authority. The limitation of the findings may lack generalizability. However, the results may be generalized in the emerging markets environment. Hence, researchers are advised to understand the facts of the case, analyze it in terms of stock exchange regulations, appreciate the appropriateness of the award, and apply the same in their future research activities in some other similar contexts in India and abroad.
\end{abstract}

\section{Keywords}

Arbitration, Margin Trading, Applicant, Respondent, Securities Market

\section{Introduction}

The paper discusses the adjudication proceedings by a sole arbitrator under the Rules, Bye-laws and Regulations of the Stock Exchange of India [1] [2] [3]. The subject matter of the case is about the appropriateness of squaring of the positions of the client (Client mode account) by a trading member of the stock exchange, when margins are adequate. The first section of the paper provides case introduction and facts of the case, second section deals with the defense of the

*This paper is based on an arbitration matter resolved through Alternative Dispute Resolution (ADR) mechanism at the leading stock exchange of India. 
respondent, third section contains a detailed analysis of the case and the last section provides with the recommendation and the arbitral award.

Applicant had registered as a constituent (client) with Respondent and used the online trading platform of Respondent to execute trades on Stock Exchanges. The Respondent is a member of the Stock Exchange of India, registered in the Capital market and Futures and Options segments. Respondent offers broking services to its clients through its portal. The website of the Respondent provides a safe and convenient access to all clients in the Capital market segment of the Stock Exchange. The Respondent offers its clients various products through its website. One such product is the "Margin Product. The Respondent offers clients' option to choose the square off mode while placing the initial order namely Client Mode or Broker Mode. Applicant bought 40,000 shares of RED Auto Industries Limited at an average price of INR 615 under T +90 days. The Applicant used Client Mode Margin product of Indian Securities Ltd and full security margin was provided. The "square off mode for the above hares of "RED Auto Industries" was chosen as "Client Square off" mode. Under the "Client Square off" mode, the Client could carry forward his buy open positions till the time as specified by the Respondent. The Applicant was aware that the positions would be permitted to be continued till the regulatory stipulated time and upon fulfillment of the necessary margin requirements as specified by Indian Securities Ltd. for a particular scrip from time to time [4].

\section{Genesis and Facts of the Case}

On June 23, 2017, at about 12:20PM, Indian Securities Ltd. trading software placed unauthorized Square-off orders from the Applicant's account for 40,000 shares of RED Auto Industries Limited. Indian Securities Ltd's system placed two orders of 20,000 shares each at INR 532 and INR 527 respectively. Out of these, 10,102 shares were executed at INR 526 and 671 shares were executed at INR 506. The system suddenly cancelled the remaining pending orders and placed fresh orders at market price (no price was set in the order). As a result, there maining shares were traded at an average rate of INR 456. Average traded volumes in the share of Red Auto Industries were normally, very low. But the order for 40,000 shares created panic in the market and resulted in steepest fall in price of the share, on that day i.e., June, 23, 2017.Prior to the placement of these orders, the day's trading pattern, price range and movement in share price were normal and no volatility was noticed. Due to this sale, the Applicant had incurred losses. Respondent didn't resolve the issue properly. Hence the Applicant approached the Stock Exchange for resolution as per bye-laws of the Exchange. The Stock Exchange referred the matter to the Investor Grievances Redress al Committee (IGRC), the first tier of dispute resolution. The Panel Member, (IGRC), could not resolve the issue amicably and referred the matter to arbitration, the next tier of dispute resolution mechanism of the Exchange. Accordingly, Applicant filed an application for Arbitration with a prayer to do justice 
by recovering his losses from the Respondent.

\section{Bone of Contention}

The client was maintaining an online trading account with the Respondent. Margin statement issued by the Respondent was evidencing sufficient and adequate margin. No notice seems to have been served on the applicant by the Respondent, intimating about the short fall in the margin account. Applicant contended that when full margin was provided in the account, Respondent did not have any right to liquidate the positions of the client. More over when, 10,102 shares and 671 shares were executed at INR 526 and INR 506 respectively, why did the Respondent cancel these limit orders and re-order them at market price? Why did the Respondent place orders to sell the shares of Red Auto Industries Ltd when the price fall was only $3 \%$ ? As per IGRC's report, RED Auto Industries Limited share prices did not fall beyond 3 per cent hence the Respondent should not have not meddled with the account of the Applicant. The Respondent's system got triggered before fall of $16 \%$ from previous day closing price. The action was unwarranted when the $\mathrm{VaR}^{1}+99 \%$ margin was provided. Holding long positions in a client mode of account was entirely at the risk of the Applicant and not that of the trading member. The job of a Trading member is to buy or sell shares as per the instructions of the client. If the Applicant's positions fall short of margins, Respondent could close out client's position with intimation. The Applicant demanded for the proof/evidence that the share price fell by 16 per cent from previous day's closing which prompted the respondent company to square off his positions in the account. Applicant alleged that Respondent submitted false and wrong information to mislead the Arbitration proceedings and wanted to escape from its system's wrong doing. The Applicant strongly condemned the action of the Respondent in squaring off his long position, in a client mode of account, when margins are adequate. The Applicant arrived at the total loss of INR 13.20 million, which represented the difference between the price of INR 820 as on July 13, 2017, (the date of complaint) and average square off price of INR 470 and claimed INR 9.9 million as compensation.

\section{Defense Statement by Respondent}

Respondent contended that the Applicant placed orders for RED Auto Industries Limited under the margin product but did not provide the full payment within two days of delivery of the contract note. Hence, the Respondent was at liberty to close out the transactions by selling the securities. Since the Applicant was a "Constituent in Default" the Respondent was at liberty to close out the transaction by selling the security. The Stock Exchange Bye-law 247 (A) (5)

${ }^{1} \mathrm{VaR}$ (Value at Risk) is a statistical technique used to estimate the probability of loss of the value of an asset or portfolio based on the statistical analysis of historical price trends and volatilities. The VaR statistic has three components: a time period, a confidence level, and a loss amount (or loss percentage). With $99 \%$ confidence, what is the maximum value that an asset or portfolio may lose for a particular point of time i.e., today or the next day. 
clearly states that in case of purchases on behalf of client, trading members have the right to sell the securities if the constituent fails to make the full payment to the trading member for the execution of the contract within two days of contract note having been delivered for cash shares. Respondent submitted that the Applicant (client) agreed that Indian Securities Ltd maystipulateashortertimethantheregulatoryprescribedtimefortakingthedeliverythereof [SEBI, 2012]. Indian Securities Ltd. Reserves the right to modify the time at its discretion. In case of purchases on behalf of client, member brokers shall be at a liberty to close out the transactions by selling the securities, in case the client fails to make the full payment to the member broker for the execution of the contract within two days of contract note having been delivered for cash shares and seven days for specified shares or before pay-in day (as fixed by Stock Exchange for the concerned settlement period), whichever is earlier; unless the client already has an equivalent credit with the trading member. The loss incurred in this regard, if any, will be met from the margin money of that client.

The Respondent further submitted that it had mentioned in the "Terms and conditions" the conditions Online, in which a position taken under the "Margin Product" would be squared off. The Online "Terms and conditions" clearly state that in case the last traded price of a security moves by a particular percentage (as specified by the Respondent) below its previous day closing price, the Respondent would have the discretion to square off its clients position without giving any notice. The client agreed that Indian Securities Ltd. would have the discretion to square off, without giving any notice, the client's position and cancelling pending orders under the facility. The Respondent submitted that the closing price of the scrip for the previous trading day i.e. June 22, 2017, was INR 540. Respondent observed that the price of the scrip on June 23, 2017 went down by more than $16 \%$ to INR 437 . Respondent squared off the client's position under the Client Mode in a particular security having a price band, when the last traded price for the security moved by $16 \%$. Respondent contended that threshold for disabling a price band stock from further trading and liquidating existing positions/orders in Margin-Broker/Clientmodeis16\% movement from previous closing in certain securities.

In the instant case, the Applicant had carried forward 40,000 shares to June 23, 2017. The closing price of RED Auto Industries on June 22, 2016 was INR $540 \mathrm{~A}$ fall of $15 \%$ in day is an indication of high volatility and increased riskiness of the scrip. In such as cenario if the trading members do not takes wiftaction, there will be heavy losses there by impacting the market functioning. Hence, 40,000 shares of RED Auto Industries which were bought by the Applicant in the "Margin Product" under "Client square off" mode were squared off by the Respondent at an average price of INR 470.The closing price of the scrip for the previous trading day i.e., June 22, 2017, was INR 540. Respondent squared off the client's position under the Client Mode in a particular security having a price band, if the last traded price for the security moves by a predefined percentage 
determined by Indian Securities Ltd. Respondent prayed for passing an order to dismiss the claim made by the Applicant.

\section{Discussion, Results and Conclusions}

Applicant purchased 40,000 shares of RED Auto Industries at an average price of INR 620. The "square off" mode for the above shares was chosen as "Client Square off" mode. Under the "Client Square off" mode, the Client could carry forward his buy open position still the time as specified by the Exchange. Respondent contended that Applicant bought 40,000 shares of RED Auto Industries Limited under the margin product but did not provide the full payment within two days of delivery of the contract note. The contention of the Respondent was neither relevant nor applicable to the purchased positions under margin facility. These shares were purchased under margin account. Under this facility, there was no requirement of full pay inn (full payment). If these were bought under cash account, there was a requirement of full pay inn in $\mathrm{T}+2$ days. In the extant instance, the Applicant bought these shares under margin product, there was no requirement of full pay inn but adequate margin had to be provided under margin rules of the Stock Exchange. Thus under cash market, full payment was mandatory and not in case of margin trading. The trading member does not seem to have clarity, knowledge and understanding about the basic fact, whether the Applicant had bought shares on cash product or margin product.

The bye-laws, rules and regulations of the Stock Exchange of India did not provide any right or discretion to the trading member (Respondent) to terminate, or square off, or liquidate the positions of clients except in case of short fall of margins. Trading members had no authority to take purchase or sale decisions of shares on behalf of clients except in case of shortage of margins in margin product or default in payment by the client in case of cash market. Investment (buying) or disinvestment (selling) of positions in margin product rests with the clients. Risks and rewards in such cases were that of client. It was observed from the margin statements of the Applicant as on June 22, 2017 and June 23, 2017, that the Applicant (client) had provided adequate and full margin for his positions. The Respondent did not inform the client regarding its intension to square off the positions on account of short fall of margins either on June 22 or June 23, 2017.

The Respondent does not have any right to square off the positions unless the share price moves beyond a certain percentage. Purchase contract notes neither specified nor indicated the conditions for square off if the price falls beyond 16 percent. The Respondent did not have any permission from the Stock Exchange or SEBI to square off client's positions if the price falls beyond certain percentage. Closing out the position of the client by the trading member in the absence of any default of payment in case of cash market or short fall of margin in case of margin trading, was nothing but unauthorized trading by the Respondent. This was in violation of margin trading regulations and noncompliance with the 
bye-laws, trading rules and regulations of the Stock Exchange. It amounted to deprivation of the basic and fundamental rights of the clients and detrimental to the interests of the public at large. It is a clear case of unfair and unethical trade practices of the trading member towards its clients.

The issue before the arbitrator was whether the Respondent was within its rights to square off the open position of the client on account of volatility of the share price when there was no short age of margins or no default in pay inn obligations from the client. The second issue was whether the share price of Red Auto Industries Ltd fell beyond 16 percent as compared to previous day closing price before placement of orders of the Applicant by the Respondent. Respondent did not submit the evidence that the share price of RED Auto Industries Ltd fell by 16 per cent from the previous day closing. Respondent submitted the day's low price was INR 437. In fact, before placing the orders for squaring off, the share price did not fall more than three per cent from previous day close. The difference between the prices of previous day closing was INR 540 and executed price of 10,102 shares at INR 526 works out INR 140, representing a fall of only 2.6 per cent from previous day close. The Respondent placed two orders of each 20,000 shares at INR $532 \& 527$ respectively and 10,102 shares and 671 shares got executed at INR 526 and at INR506 respectively. Then the system itself suddenly cancelled these orders and replaced the order sat market price (no price was set in the orders), and all there maining shares got executed between INR 459 and 455 . It could be concluded that the unwarranted trading was on account of Indian Securities Ltd trading system's technical snag or error or problem.

The Respondent neither explained nor clarified to the arbitrator as to why the System placed orders for each 20,000 shares at INR 532 and at INR 527 respectively and cancelled these orders. The Respondent supported its action in squaring the positions in the client account stating that there was a fall in the price of the stock by more than 16 per cent, by taking in to account the previous day's closing price and the trading day's closing price. In fact the steep fall in the market prices on the day of trading is on account of the unwarranted large scale sale of securities by the Respondent. It was observed from the submissions, that the Respondent was neither certain nor having any clarity why Applicant's positions were liquidated. Instead of identifying and ascertaining the correct reasons and causes for these unauthorized trades, Respondent was trying to provide different reasons, pre texts and causes such as risk management, volatility, default in payment and margin short fall etc. Respondent could not provide any evidence whether it had obtained permission or approval to modify the margin product of the Stock Exchange either from Stock Exchange of India or SEBI. Respondent had erroneously modified and ignorantly tampered the margin product of the Stock Exchange without any approval either from Stock Exchange of India or SEBI. Respondent claimed that it had got the ample discretion or authority of squaring off the positions of the clients in order to protect the interests of inves- 
tors by curtailing the risks of its clients and securities market. However the action of the respondent caused loss to the Applicant and resulted volatility in the scrip.

In the case matter, Applicant (client) had provided full margin for 40,000 shares of Red Auto Industries as on June 22 and June 23, 2017 as per margin statement issued by the Respondent. The risks and rewards of the investment i.e. long positions (purchases on margin facility) pass on from sellers to the buyers rather than to trading members. Trading members buy or sell shares on behalf of clients based on clients' instructions. Respondent appeared to lack clarity about the risks and rewards associated with the margin positions. Respondent was under wrong impression that squaring off clients' positions was a great benefit to clients but in fact Respondent contributed for the huge losses of the Applicant .The second issue of share nor applicable in this case as Applicant had provided adequate and full margins. SEBI provided rules and regulations for squaring off positions of the clients by trading members. As per the circular, the trading member is not authorized to square off client's position, if client maintains adequate margins for positions irrespective of steep fall or rise. The Applicant suffered losses on his positions as a result of the unnecessary and unauthorized liquidation of 40,000 shares at an average priceofINR470. The loss per share wasINR150 (purchase price of a share INR 620 square off price of share INR470) and the total loss on the square off worked out to INR 6.00 million [40,000 shares@ INR 150]. Had the Applicant wanted to purchase 40,000 shares of Red Auto Industries, to have status quo position, he should purchase the shares on the next trading day, at an average price of INR 520 (the next trading day was, June 27, 2017 with a high price of INR540and low price of INR 500). The Applicant had to pay additional cost of INR 50 per share from the square off price (INR 520-470). It amounted to INR 2.0 million (40,000 shares@ INR 50). The total loss to the Applicant on account of liquidation of his position by the Respondent was INR 8.00 million (INR 6.00 million plus INR 2.0 million). The loss of INR 8.00 million suffered by the Applicant was on account of unauthorized trading indulged by the Respondent. Therefore, Respondent was account able and responsible to compensate the loss to the Applicant.

\section{Recommendation (The Award)}

In view of the foregoing submissions, documents, rejoinders, hearings, and arguments of the parties, and on the basis of arbitrator's observations, findings and conclusions, the loss incurred by the Applicant was on account of unauthorized trades indulged by the Respondent. Hence based on the principles of equity, fairness and natural justice, the loss has to be borne by the Respondent. The Respondent, (Indian Securities Ltd.) was directed to pay an amount of INR 8.00 million (Rupees eight million only) to the Applicant with an interest of 16 per cent per annum from the date of the award till payment. The parties were directed to bear their own costs. 


\section{References}

[1] SEBI (2010) Arbitration Mechanism in Stock Exchanges. CIR No. /MRD/DSA/29, 1-4.

[2] SEBI (2012) Rights and Obligations of Stock Brokers. Sub Brokers and Clients Issued by the SEBI, Mumbai, 1-15.

[3] SEBI (2017) Circular on Comprehensive Review of Margin Trading Facility. Circular No. CIR/MRD/DP/54/2017, 1-8.

[4] The Arbitration and Conciliation Act of India 1996, India, 1-26. 